\title{
Diversity and Influence of Environmental Factors on the Spatio-Temporal Distribution of the Ichthyofauna of Malonda Lagoon (Congo Brazzaville)
}

\author{
Tenda Hélène Dembe Louvinguila1,2, Armel Ibala Zamba1,2* ${ }^{10}$, Victor Mamonekene ${ }^{1,2}(\mathbb{0}$, \\ Lérège Batiabo Mikembi ${ }^{2}$, Freedom Honest Poaty Ngot $^{2}$, Joseph Goma-Tchimbakala1,2 \\ ${ }^{1}$ Ecole Nationale Supérieure d'Agronomie et de Foresterie (ENSAF), Université Marien Ngouabi, Brazzaville, \\ République du Congo \\ ${ }^{2}$ Institut national de Recherche en Sciences Exactes Naturelles, Laboratoire de l'Environnement et Océanographie, Brazzaville, \\ République du Congo \\ Email: ^ibalaszamba@yahoo.fr
}

How to cite this paper: Dembe Louvinguila, T.H., Zamba, A.I., Mamonekene, V., Mikiembi, L.B., Ngot, F.H.P. and Goma-Tchimbakala, J. (2021) Diversity and Influence of Environmental Factors on the Spatio-Temporal Distribution of the Ichthyofauna of Malonda Lagoon (Congo Brazzaville). Natural Resources, 12, 147-163. https://doi.org/10.4236/nr.2021.125011

Received: March 1, 2021

Accepted: May 28, 2021

Published: May 31, 2021

Copyright $\odot 2021$ by author(s) and Scientific Research Publishing Inc. This work is licensed under the Creative Commons Attribution International License (CC BY 4.0).

http://creativecommons.org/licenses/by/4.0/

\begin{abstract}
This study was initiated with the aim of studying the diversity and spatio-temporal distribution of fish in the Malonda lagoon, one of the coastal ecosystems of the Base Guinea in the Republic of Congo. The fish were sampled over a period of two years in three zones each including three stations known as: Mangrove, Grass and Full water. One station upstream towards the freshwater zone, one station downstream towards the mouth and one station in the containment zone. The catches were made using monofilament gillnets of 8,10, 20 and $30 \mathrm{~mm}$ mesh size. During the rainy season, 1516 specimens belonging to 29 species, 17 families and 12 orders were collected. In the dry season, 768 specimens belonging to 20 species, 11 families and 8 orders were collected. For both seasons, the family Cichlidae is the most diversified. The marine forms are the most represented compared to the continental forms. Redundancy Analysis with forward selection coupled with Monte Carlo permutation tests showed that in the rainy season four variables influenced the distribution of species (Depth: 48\%, Vase: 16\%, Nitrogen: 10\% and Transparency: $10 \%)$; in the dry season three variables influenced the distribution of species (Vase: 38\%, Nitrogen: 14\% and Oxygen: 11\%). Ecological indices showed that the Malonda lagoon is already undergoing either anthropic or natural impacts, its state of ecological integrity is disturbed, the values of Shannon diversity and Equitability indices are not close to maximum values. The results of this study will serve as an ecological database for the proper
\end{abstract}


management of these ecosystems.

\section{Keywords}

Fish, Ecology, Distribution, Season, Malonda Lagoon, Lower Guinea

\section{Introduction}

Aquatic ecosystems are highly diversified in terms of their origin, formation and functioning, as well as in terms of the rich fauna and flora they contain [1]. African ichthyological provinces in general and that of Lower Guinea in particular, which covers the coastal rivers of Cameroon and Gabon, right up to the mouth of the Congo, cover a rich and varied fauna [2] [3]. Lagoons which are part of coastal ecosystems are considered among the most productive aquatic environments thanks to their high rates primary production [4] [5] [6]. They offer very high biological diversity and constitute a real ecological niche [6]. The richness of African estuaries and lagoons is higher compared to others on a global scale. Just like the physical environment, the fauna and flora of these environments are influenced by the adjacent systems in a balance depending on the situation [4]. The faunal assemblages that occupy these poorly defined spaces present more or less random aggregates of opportunistic fish originating either from the neighboring continental shelf or from continental tributaries [4]. The specific composition and structure of fish populations in a given place result from the action of a series of ecological filters [7], including the strength and duration of floods, the physico-chemical characteristics of the water and their spatio-temporal variations [8] [9], trophic richness, and the presence and condition of mangroves [9]. Interactions between migrating species and resident ichthyofauna contribute significantly to the structuring of fish populations [10]. The composition of settlements is also modified, sometimes considerably, by human interventions, such as the construction of works (port facilities, dykes, dams), the development of communications with the ocean, fishing and aquaculture activities, pollution linked to urbanization and industrialization and agricultural activities [11] [12]. These activities can have significant and uncontrolled consequences on the entire lagoon hydrosystem from the catchment area to the sea [13]. The hydrodynamics and hydrochemistry resulting from the confrontation of bodies of water of different origin and chemical composition constitute an essential element of the lagoon ecology, intervening directly on the specific composition, structure and spatio-temporal distribution of the communities but also on the dynamics of the various populations: migration, reproduction rate, growth [14] [15].

In Congo, lagoons are even less studied and require in-depth environmental studies to better understand and manage them. The present study was conducted in the Malonda lagoon, to contribute to the basic enrichment of data on 
the diversity and ecology of the fish in these waters. In particular, the study provides data on the inventory of ichthyodiversity, the analysis of the spatio-temporal distribution and the distribution of fish species in relation to environmental variables.

\section{Material and Methods}

\subsection{Study Area and Fish Sampling}

The fish used in this study were collected in the Malonda lagoon, located in the south of the Republic of Congo, in the Department of Pointe-Noire (Figure 1). Fed by the waters of the Loémé River, the Malonda lagoon covers about 95 ha. It communicates temporarily with the ocean. It thus opens up to the ocean naturally in the rainy season and remains closed in the dry season.

A total of three areas were sampled, each including three stations: Mangrove $(\mathrm{Mg})$, Grass $(\mathrm{Hb})$ and Open Water (Pe) (Figure 1). Zone I (Mg1, Hb1 and Pe1) is located upstream near the Loémé, Zone II ( $\mathrm{Mg} 2, \mathrm{Hb} 2$ and $\mathrm{Pe} 2)$ is in the containment zone and Zone III ( $\mathrm{Mg} 3, \mathrm{Hb} 3$ and $\mathrm{Pe} 3$ ) towards the lagoon ambushes. The choice of stations was made as a function of 1) the distance from the mouth in order to assess the spatial variability of the physicochemical parameters subject to the hydroclimatic variations of the Loémé River, 2) accessibility and 3) the presence of the three stations (Figures 2(A)-(C)). Eight data collection campaigns were carried out between January 2018 and August 2019, including

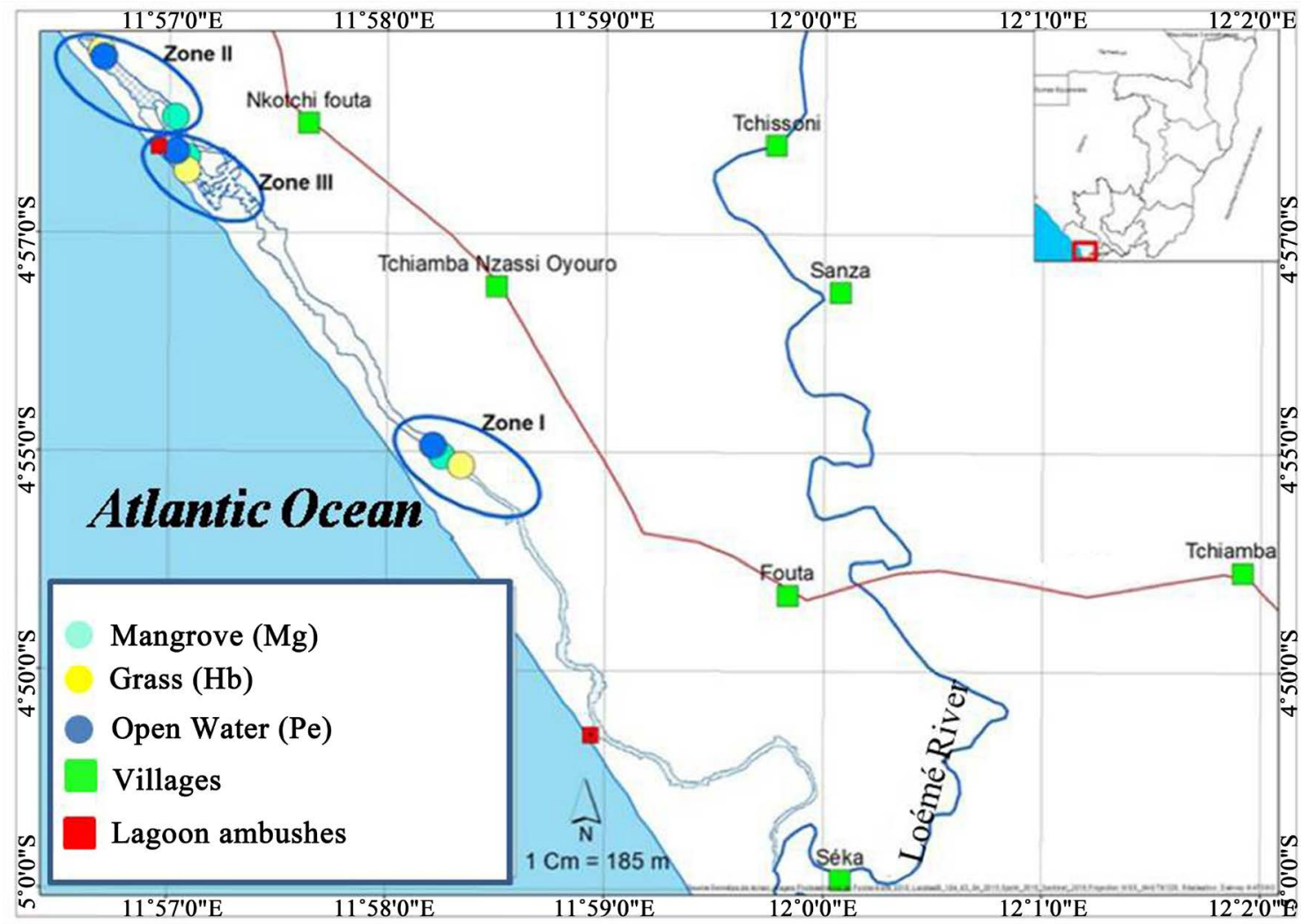

Figure 1. Malonda Lagoon and sampled stations. 
four in the rainy season (January and April) and four in the dry season (July and August).

At each of the stations, fishing was carried out between $5 \mathrm{pm}$ and 7 am (Figure 3(A) \& (Figure 3(B)), following a standardised catch method using 8 , 10, 20 and $30 \mathrm{~mm}$ mesh size gillnets see [16] [17]. Harvested fish were identified in the field. Those whose identifications were uncertain in the field were preserved in $10 \%$ formalin for identification at the ichtyological laboratory of the National Institute for Research in Exact and Natural Sciences (IRSEN). Families
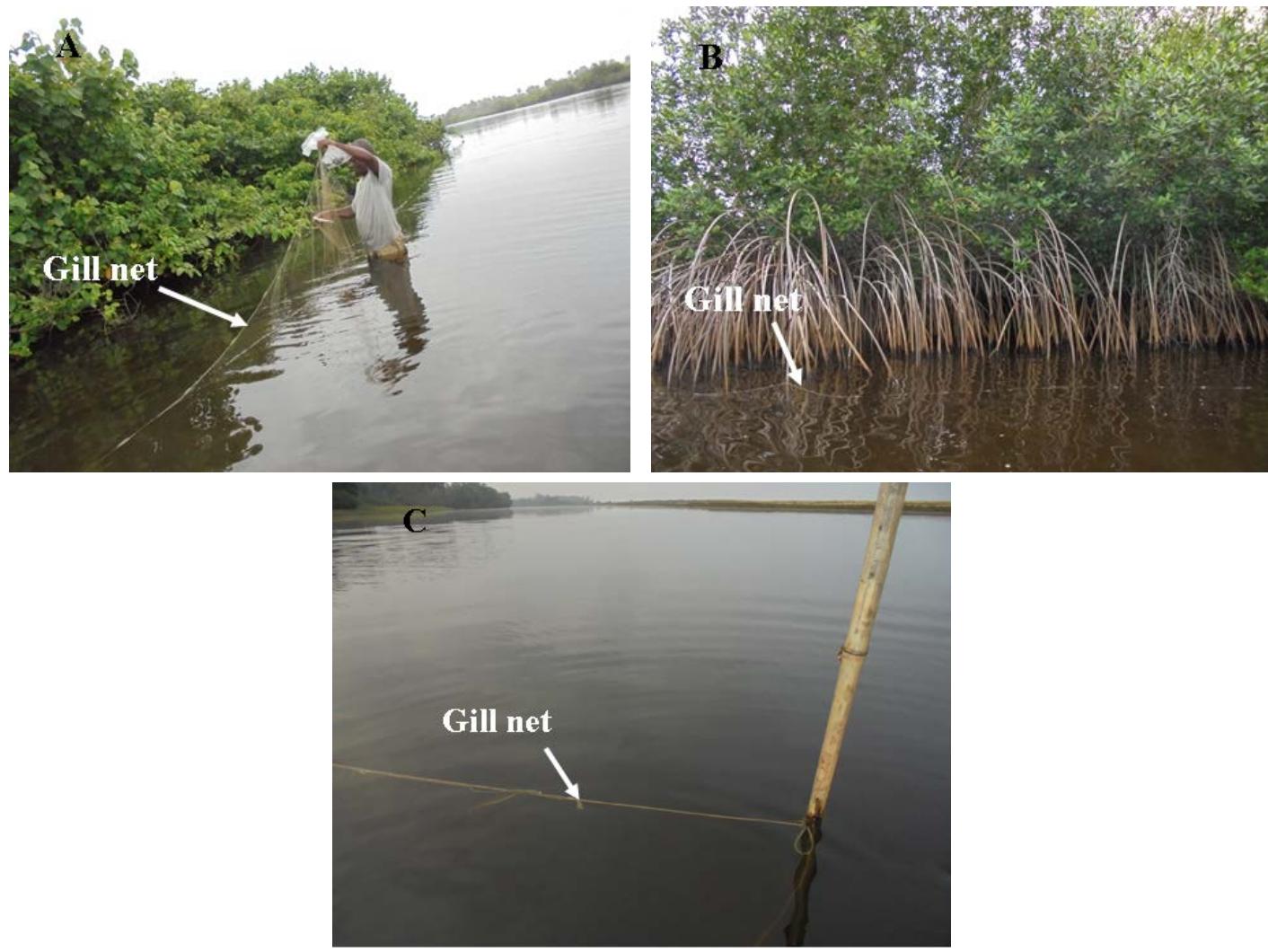

Figure 2. Sampling stations. (A): Grass station; (B): Mangrove station; (C): Full water station.
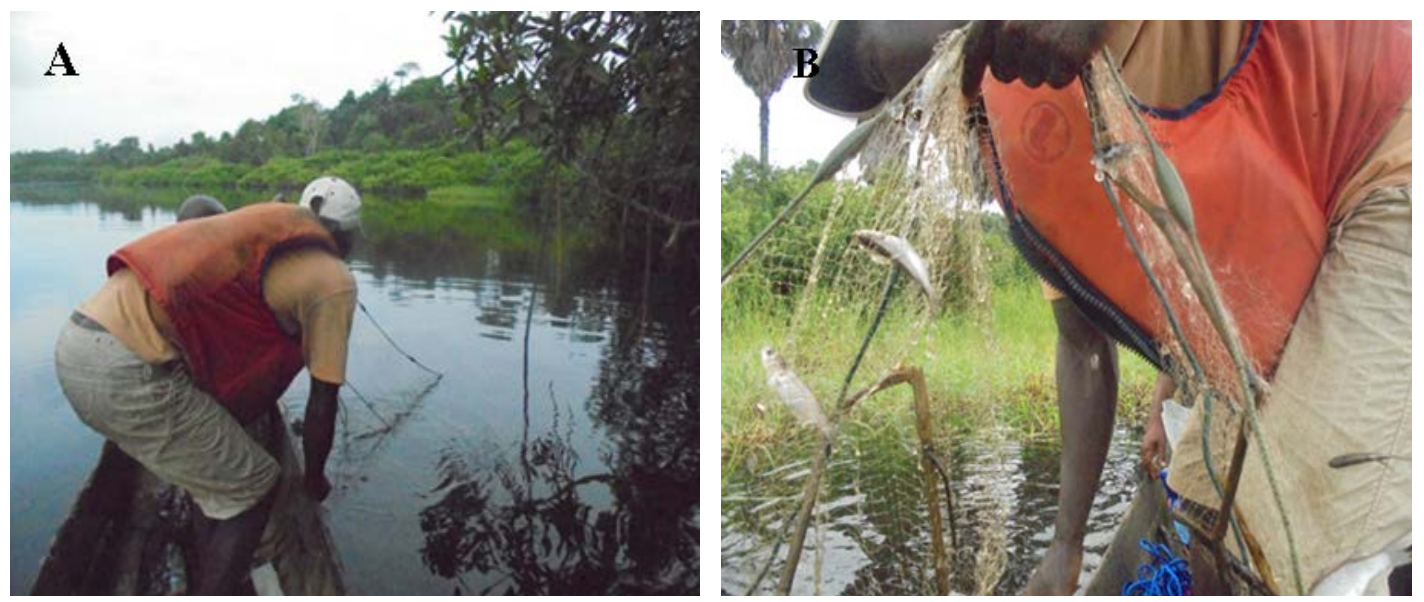

Figure 3. Removing the nets. (A): Net laying (Mangrove station); (B): Net removal (Grass station). 
were classified according to [18], while genera and species were classified in alphabetical order.

\subsection{Measurement of Environmental Variables}

A total of thirteen environmental variables were measured at each station studied for this study (Table 1). Physicochemical parameters $(\mathrm{pH}$, temperature, conductivity, salinity and total dissolved solids) were sampled in situ using a multi-parameter probe (Oakton Pcstestr 35). Transparency was measured using a Secchi disk. Nitrogen (by the Kjeldahl method converts to organic nitrogen), phosphorus (by the Riley and Murphy reagent method) and dissolved oxygen (by the cold potassium permanganate method) were measured at the chemistry laboratory of "Institut national de Recherche en Sciences Exactes et Naturelles (IRSEN)" in Pointe-Noire. The values represented for all the variables are the averages obtained over eight campaigns. In each of the prospected stations, the parameters were taken twice in the rainy season and twice in the dry season, for two years $\left(\mathrm{n}=2\right.$ days ${ }^{*} 2$ seasons ${ }^{*} 2$ years $\left.=8\right)$.

The type of substrate was estimated as a percentage of the total substrate. Three types of substrates were determined: sand (Sab), mud (Vase) and rock (Aut).

\subsection{Data Analysis}

Based on the significant seasonal differences $(\mathrm{P}<0.05)$ found in $60 \%$ of the environmental parameters measured (Table 1), the treatments were made considering the effects of the season. The length of the gradient $(\mathrm{LG}<3)$, provided by

Table 1. Means and test of variances of physico-chemical parameters for two days, two seasons and two years $(n=8)$, in bold are the variables with seasonal differences Significant. Values SD: Standard deviation.

\begin{tabular}{cccccc}
\hline & & & & \multicolumn{2}{c}{ T test } \\
Environmental variables & Codes & $\begin{array}{c}\text { Rainy season } \\
\text { Mean } \pm \text { SD }\end{array}$ & $\begin{array}{c}\text { Dry season } \\
\text { Mean } \pm \text { SD }\end{array}$ & t-value & P \\
\hline Temperature $\left({ }^{\circ} \mathrm{C}\right)$ & Temp & $30.58 \pm 0.29$ & $26.57 \pm 0.13$ & 37.48 & $<0.001$ \\
$\mathrm{pH}$ & $\mathrm{pH}$ & $6.92 \pm 0.10$ & $6.95 \pm 0.17$ & -0.47 & 0.64 \\
Salinity $(\mathrm{ppt})$ & $\mathrm{Sali}$ & $0.67 \pm 0.25$ & $3.39 \pm 0.23$ & -23.69 & $<0.001$ \\
Conductivity $(\mathrm{mS} / \mathrm{cm})$ & $\mathrm{Cond}$ & $1.71 \pm 0.62$ & $7.98 \pm 0.50$ & -23.6 & $<0.001$ \\
Total dissolved solids $(\mathrm{ppt})$ & $\mathrm{Tds}$ & $1.22 \pm 0.45$ & $5.70 \pm 0.39$ & -22.51 & $<0.001$ \\
Transparency $(\mathrm{cm})$ & $\mathrm{Trans}$ & $47.62 \pm 5.34$ & $67.55 \pm 5.51$ & -3.65 & 0.002 \\
Depth $(\mathrm{m})$ & $\mathrm{Prof}$ & $2,72 \pm 1.22$ & $2.03 \pm 1.25$ & 1.18 & 0.25 \\
Nitrogen $(\mathrm{mg} / \mathrm{L})$ & $\mathrm{N}$ & $2,78 \pm 0.74$ & $0.43 \pm 0.23$ & 9.09 & $<0.001$ \\
Phosphorus $(\mathrm{mg} / \mathrm{L})$ & $\mathrm{P}$ & $0.12 \pm 0.02$ & $0.10 \pm 0.11$ & 0.54 & 0.3 \\
Dissolved oxygen $(\mathrm{mg} / \mathrm{L})$ & $\mathrm{O}{ }_{2}$ & $13.4 \pm 1.68$ & $13.91 \pm 9.89$ & -0.15 & 0.88 \\
\hline
\end{tabular}


the DCCA, made it possible to opt for the Redundancy Analysis (RDA), to understand the correlations between species and environmental variables. Two matrices were simultaneously used, one of the numerical abundances of species and the other of environmental variables. Before any ordination, species abundances were transformed into $\log (\mathrm{x}+1)$, while environmental variables were transformed into $\ln (x+1)$, or $\arcsin \sqrt{x}$ for percentage data [12] [17] [19] [20] [21]. The Monte Carlo test (999 permutations, $\mathrm{p}<0.05$ ) was carried out to select the variables that significantly explain the distribution of species. These analyses were performed using CANOCO 4.5 for Windows [22].

In order to assess the state of ecological health of the lagoon, three diversity indices, commonly used in ecology [23] [24] were calculated using PRIMER version 5 software [25]: species richness (S), Shannon index $(H)$ and Equitability (R). The species richness ( $S$ ) corresponds to the number of species present in the sample. The Shannon diversity index $H^{\prime}$ [26] calculated according to the formula:

$$
H^{\prime}=-\sum_{i=1}^{S} P i \ln P i
$$

with $P i=n i l N ; N$ being the total number of individuals obtained for all species, $n_{i}$ is the number of individuals of species $i$ and $\mathrm{P} i$ the relative abundance of species $i$ in the sample. Shannon index varies between 0 and $H^{\prime}$ maximum, calculated according to the formula: $H_{\max }^{\prime}=\ln S$.

The Equitability (R) [27] indicates whether individuals are equally distributed among the species of the target area, and varies between 0 and 1 . It tends towards 0 when the totality of catches is almost entirely of one species, and towards 1 when all species have the same abundance within given sample. It is calculated using the formula:

$$
R=H^{\prime} / H_{\max }^{\prime}
$$

\section{Results}

\subsection{Species Composition}

The composition of the fish diversity of the Malonda Lagoon is recorded in Table 2. Overall, a total of 2284 specimens belonging to 33 species, 17 families and 12 orders have been reported. Among the fish families sampled, Cichlidae ( $\mathrm{n}=7$ species), Mugilidae and Eleotridae ( $\mathrm{n}=4$ each), Carangidae $(\mathrm{n}=3)$ and Clupeidae $(n=2)$ are the five most represented. The other twelve families are less represented with one species each.

Depending on the season, 1516 specimens divided into 29 species, 17 families and 12 orders were caught during the rainy season. The family Cichlidae is the most diversified ( $\mathrm{n}=6$ species) followed by Eleotridae $(\mathrm{n}=4)$, Carangidae $(\mathrm{n}=$ $3)$ and Mugilidae $(n=2)$. The other families are less diversified with one species each. During the dry season, 768 specimens belonging to 20 species, 11 families and 8 orders were reported. The family Cichlidae is the most diversified ( $n=5$ 
Table 2. List of species collected, their codes and relative abundance. ${ }^{*}$ : species with marine affinity; RS: rainy season; DS: dry season.

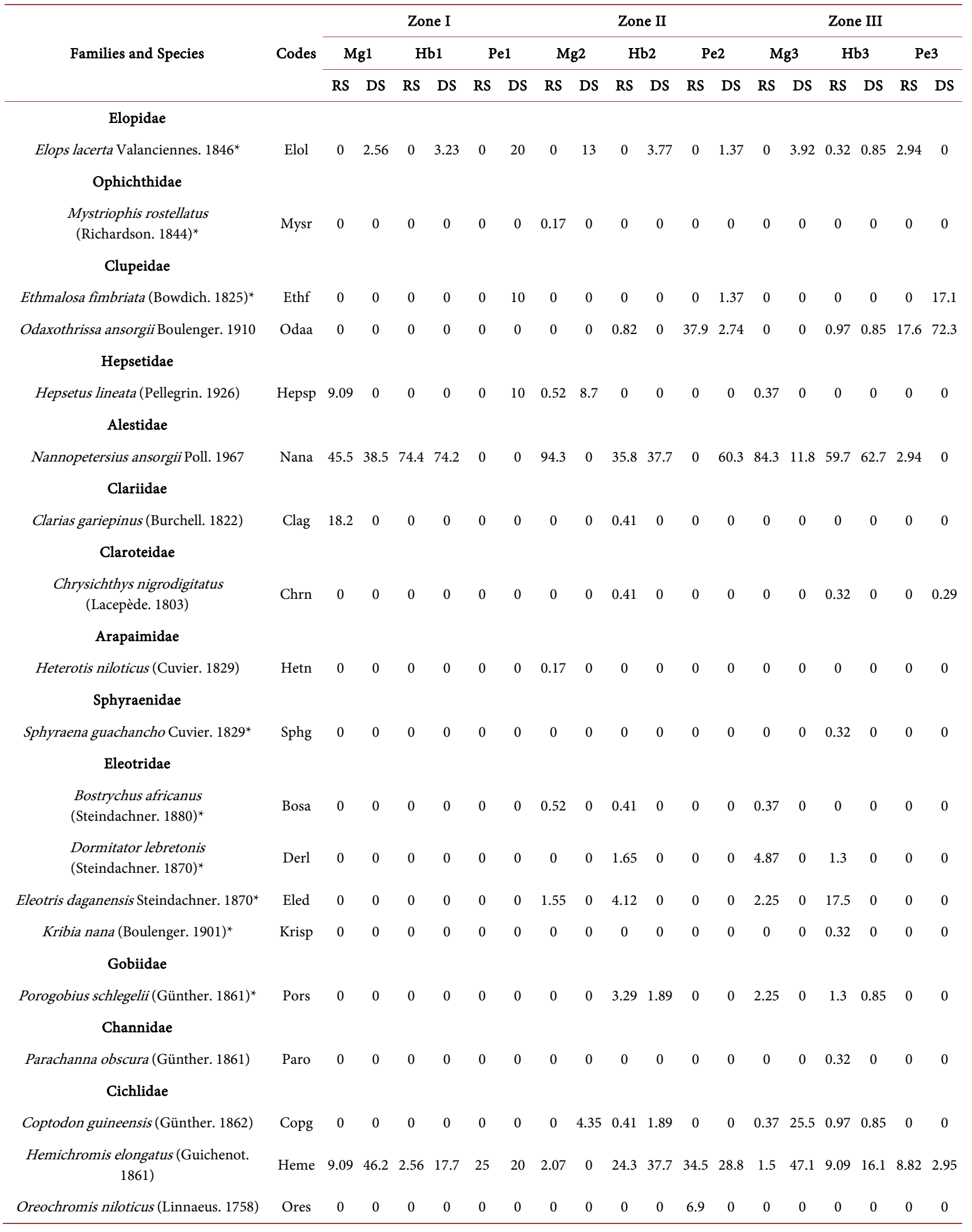




\section{Continued}

\begin{tabular}{|c|c|c|c|c|c|c|c|c|c|c|c|c|c|c|c|c|c|c|c|}
\hline Oreochromis schwebischi (Sauvage. 1884) & Oren & 0 & 0 & 0 & 0 & 0 & 0 & 0 & 65.2 & 0 & 13.2 & 0 & 0 & 0 & 0 & 0 & 0 & 0 & 0 \\
\hline Pelmatolapia cabrae (Boulenger. 1899) & Pelc & 0 & 0 & 0 & 0 & 0 & 0 & 0 & 4.35 & 0.82 & 0 & 0 & 1.37 & 0 & 0 & 0.97 & 0 & 5.88 & 0.59 \\
\hline $\begin{array}{l}\text { Sarotherodon melanotheron Rüppell. } \\
1852\end{array}$ & Sarm & 9.09 & 0 & 2.56 & 0 & 50 & 0 & 0.52 & 0 & 4.12 & 0 & 10.3 & 0 & 0 & 0 & 0.32 & 0 & 5.88 & 0 \\
\hline $\begin{array}{l}\text { Sarotherodon nigripinnis dolloi Riippell. } \\
1852\end{array}$ & Sarsp & 9.09 & 0 & 0 & 0 & 0 & 10 & 0.17 & 0 & 0.41 & 0 & 0 & 0 & 0 & 0 & 0 & 0 & 0 & 0 \\
\hline \multicolumn{20}{|l|}{ Mugilidae } \\
\hline Mugil bananensis (Pellegrin. 1928)* & Mugb & 0 & 0 & 0 & 0 & 0 & 0 & 0 & 0 & 0 & 0 & 0 & 0 & 0 & 0 & 0 & 0 & 0 & 1.18 \\
\hline Mugil curema Valenciennes. $1836^{*}$ & Mugcr & 0 & 0 & 0 & 0 & 0 & 0 & 0 & 0 & 0 & 0 & 0 & 0 & 0 & 0 & 0.32 & 0.85 & 0 & 0 \\
\hline $\begin{array}{l}\text { Neochelon falcipinnis (Valenciennes. } \\
\qquad 1836)^{\star}\end{array}$ & Neof & 0 & 12.8 & 20.5 & 4.84 & 25 & 30 & 0 & 4.35 & 16 & 1.89 & 10.3 & 1.37 & 3.75 & 9.8 & 5.84 & 15.3 & 38.2 & 1.77 \\
\hline \multicolumn{20}{|l|}{ Carangidae } \\
\hline $\begin{array}{l}\text { Caranx fischeri Smith-Vaniz \& Carpenter. } \\
\qquad 2007^{\star}\end{array}$ & Carf & 0 & 0 & 0 & 0 & 0 & 0 & 0 & 0 & 0 & 0 & 0 & 0 & 0 & 0 & 0 & 0 & 2.94 & 0.29 \\
\hline Caranx hippos (Linnaeus. 1766)* & Carh & 0 & 0 & 0 & 0 & 0 & 0 & 0 & 0 & 0 & 0 & 0 & 0 & 0 & 0 & 0 & 0 & 2.94 & 0 \\
\hline Trachinotus ovatus (Linné. 1758)* & Trao & 0 & 0 & 0 & 0 & 0 & 0 & 0 & 0 & 0 & 0 & 0 & 1.37 & 0 & 0 & 0 & 0 & 2.94 & 1.18 \\
\hline Trachinotus teraia Cuvier. $1832^{*}$ & Trat & 0 & 0 & 0 & 0 & 0 & 0 & 0 & 0 & 0 & 0 & 0 & 0 & 0 & 0 & 0 & 0 & 2.94 & 0 \\
\hline \multicolumn{20}{|l|}{ Gerreidae } \\
\hline $\begin{array}{l}\text { Eucinostomus melanopterus (Bleeker. } \\
\qquad 1863)^{\star}\end{array}$ & Eucm & 0 & 0 & 0 & 0 & 0 & 0 & 0 & 0 & 7 & 1.89 & 0 & 0 & 0 & 0 & 0 & 0 & 0 & 0.88 \\
\hline Pomadasys jubelini (Cuvier. 1830)* & Pomj & 0 & 0 & 0 & 0 & 0 & 0 & 0 & 0 & 0 & 0 & 0 & 1.37 & 0 & 1.96 & 0 & 0.85 & 5.88 & 1.18 \\
\hline
\end{tabular}

species) followed by Mugilidae $(\mathrm{n}=4)$, Carangidae and Clupeidae $(\mathrm{n}=2$ each). The other nine families each have one species.

\subsection{Fish Community Assemblages in Relationship to Environmental Variables}

Results of the Redundancy Analysis (RDA) show the different correlations between species, between environmental variables and stations, between species and different stations (Figure 4 and Figure 5). In the rainy season, the first two axes (respectively 55.8 and 19\%) express $74 \%$ cumulative variance of the species data (Figure 4), with a very high correlation between species and environmental variables for both axes (respectively 0.92 and 0.81 ). The Monte Carlo test (999 permutations) shows that both axes are significant $(\mathrm{F}=1.89$; $P=0.004)$. Redundancy Analysis with forward selection identified four variables $(P<0.05)$, which together express $84 \%$ of the total variance: Depth (Prof: $48 \%$ ), Vase (Vase: 16\%), Nitrogen (N: 10\%) and Transparency (Trans: 10\%).

In the dry season, the first two axes (respectively $50.2 \%$ and $9.5 \%$ ) express $59.7 \%$ cumulative variance of species data (Figure 5). The correlation between species and environmental variables is very high for the first axes (respectively 
0.96 and 0.78.) The Monte Carlo test (999 permutations) shows that both axes are significant $(\mathrm{F}=3.03 ; P=0.01)$. Three significant environmental variables $(P$ $<0.05)$ were selected, expressing alone $63 \%$ of the total variance in community structure: Vase (Vase: $38 \%)$, Nitrogen (N: 14\%) and Oxygen $\left(\mathrm{O}_{2}: 11 \%\right)$.

The variables selected for both seasons influence the distribution of fish communities. The analysis of Figure 4 shows that in the rainy season the stations are classified into four habitat types in relation to the two axes. Habitat 1 includes three stations ( $\mathrm{Hb} 2, \mathrm{Hb} 3$ and $\mathrm{Mg} 3$ ), is positively correlated with Axis 1 but negatively correlated with depth, the characteristic species are: Bostrychus africanus, Chrysichthys nigrodigitatus, Coptodon guineensis, Dormitator lebretonis, Eleotris daganensis, Elops lacerta, Eucinostomus melanopterus, Hemichromis elongatus, Kribia nana, Mugil curema, Nannopetersius ansorgii, Neochelon falcipinnis, Parachanna obscura, Pelmatolapia cabrae, Porogobius schlegelii, Sarotherodon melanotheron and Sphyraena guachancho. Habitat 2 with two stations ( $\mathrm{Pe} 3$ and $\mathrm{Pe} 2)$ is negatively correlated with axis 1 and with mud there are species such as Caranx fischeri, C. hippos, Odaxothrissa ansorgii, Oreochromis schwebischi, Pomadasys jubelini, Trachinotus teraia, and T. ovatus. Habitat 3
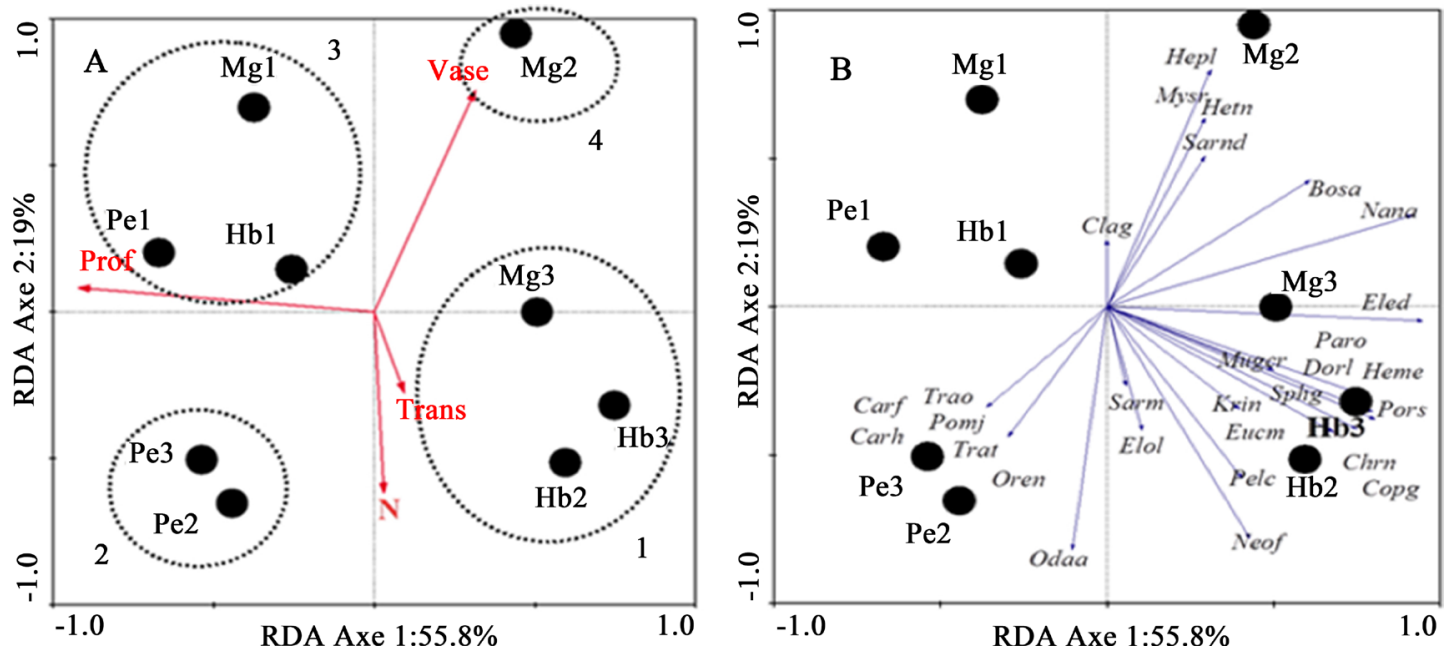

Figure 4. RDA Rainy season. Ordering of species, stations and selected environmental variables (A): Biplot of environmental variables and stations; (B): Biplot of species and stations.
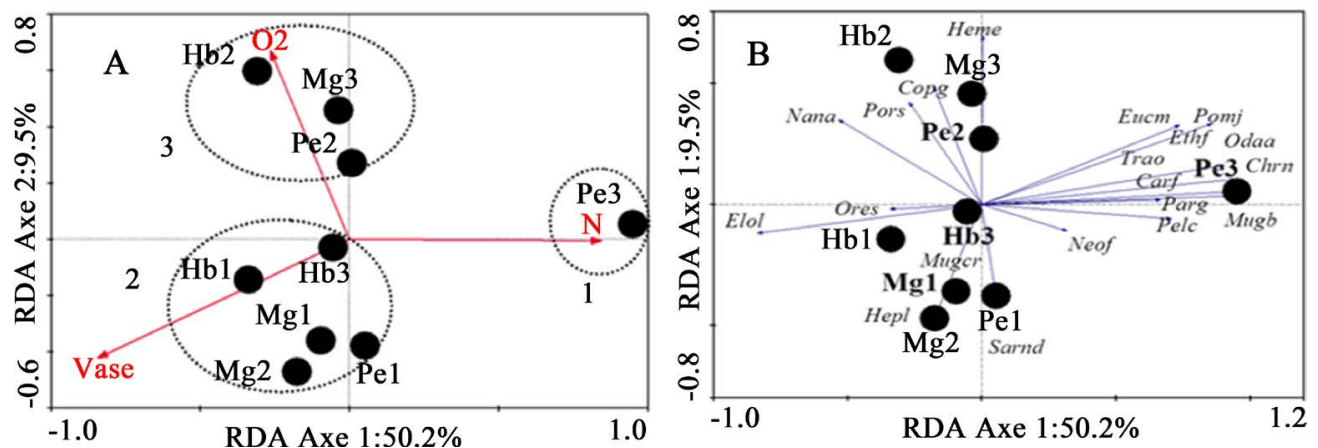

Figure 5. RDA of the dry season. Ordering of species, stations and selected environmental variables (A): Biplot of environmental variables and stations; (B): Biplot of species and stations. 
with three stations ( $\mathrm{Mg} 1, \mathrm{Hb} 1$ and $\mathrm{Pe} 1$,) influenced by depth is negatively correlated with axis 1 and positively correlated with axis 2, a single species Clarias gariepinus. Habitat 4 with only one station (Mg2), influenced by mud is positively correlated with axis 2, the main species are Hepsetus lineata, Heterotis niloticus, Mystriophis rostellatus and Sarotherodon nigripinnis.

In the dry season, three types of habitat can be distinguished (Figure 5): Habitat 1 , a single station ( $\mathrm{Pe} 3$ ), positively correlated with axis 1 and nitrogen, characterized by the species Caranx fischeri, Chrysichthys nigrodigitatus, Ethmalosa fimbriata, Eucinostomus melanopterus, Mugil bananensis, Neochelon falcipinnis, Odaxothrissa ansorgii, Parachelon grandisquamis, Pelmatolapia cabrae, Pomadasys jubelini and Trachinotus ovatus. Habitat 2 (Hb1, Mg1 Pe1, Mg2 and $\mathrm{Hb} 3$ ) is positively correlated with mud, but negatively correlated with both axes, we find Elops lacerta, Hepsetus lineata, Mugil curema, Oreochromis schwebischi and Sarotherodon nigripinnis. Habitat 3 ( $\mathrm{Hb} 2, \mathrm{Pe} 2$ and $\mathrm{Mg} 3$ ), is negatively correlated with axis 1 , but positively correlated with axis 2 and oxygen, as characteristic species Coptodon guineensis, Hemichromis elongatus, Nannopetersius ansorgii and Porogobius schlegelii.

\subsection{Spatial and Temporal Variation of Ecological Diversity Indices}

For each of the nine sampled stations, diversity indices including species richness $(\mathrm{S})$, Shannon index $(H)$, maximum Shannon index $\left(H_{\max }^{\prime}\right)$ and equitability $(\mathrm{R})$ were calculated (Table 3 ). The high values of the $\mathrm{S}, \mathrm{R}$ and $H^{\prime}$ indices during the rainy season, were observed in the stations $\mathrm{Hb} 3(\mathrm{~S}=16$ species $), \operatorname{Pe} 1(\mathrm{R}=0.95)$ and Pe3 $\left(H^{\prime}=2.01\right)$. Low values were observed in the stations Pe1 $(\mathrm{S}=3), \mathrm{Mg} 3(\mathrm{R}$ $=0.32)$ and $\operatorname{Mg} 2\left(H^{\prime}=0.31\right)$. During the dry season, high values were observed in stations $\operatorname{Pe} 3(\mathrm{~S}=12), \operatorname{Pe} 1(\mathrm{R}=0.95)$ and $\mathrm{Pe} 1\left(H^{\prime}=1.70\right)$. Low values were reported in the stations $\mathrm{Mg} 1$ and $\mathrm{Hb} 1(\mathrm{~S}=4), \operatorname{Pe} 3(\mathrm{R}=0.40)$ and $\mathrm{Hb} 1\left(H^{\prime}=0.79\right)$.

Table 3. Ecological diversity indices. $N$ : number of specimens; $S$ : Species richness; $H^{\prime}$ : Shannon index; $H_{\max }^{\prime}$ : Shannon maximum index; $R$ : Equitability; RS: rainy season; DS: dry season.

\begin{tabular}{|c|c|c|c|c|c|c|c|c|c|c|c|}
\hline \multirow{2}{*}{ Stations } & \multirow{2}{*}{ Code } & \multicolumn{2}{|c|}{$S$} & \multicolumn{2}{|c|}{$\mathrm{N}$} & \multicolumn{2}{|c|}{$H^{\prime}$} & \multicolumn{2}{|c|}{$H_{\max }^{\prime}$} & \multicolumn{2}{|c|}{$\mathrm{R}$} \\
\hline & & RS & DS & RS & DS & RS & DS & RS & DS & RS & DS \\
\hline \multirow{3}{*}{ Zone I } & Mg1 & 6 & 4 & 11 & 39 & 1.54 & 1.08 & 1.79 & 1.39 & 0.86 & 0.78 \\
\hline & Hb1 & 4 & 4 & 39 & 62 & 0.73 & 0.79 & 1.39 & 1.39 & 0.53 & 0.57 \\
\hline & Pe1 & 3 & 6 & 4 & 10 & 1.04 & 1.69 & 1.1 & 1.79 & 0.95 & 0.95 \\
\hline \multirow{3}{*}{ Zone II } & $\mathrm{Mg} 2$ & 9 & 6 & 581 & 17 & 0.31 & 1.39 & 2.19 & 1.79 & 0.14 & 0.78 \\
\hline & $\mathrm{Hb} 2$ & 15 & 8 & 243 & 48 & 1.83 & 1.32 & 2.71 & 2.08 & 0.67 & 0.63 \\
\hline & $\mathrm{Pe} 2$ & 5 & 9 & 29 & 73 & 1.39 & 1.11 & 1.61 & 2.20 & 0.86 & 0.51 \\
\hline \multirow{3}{*}{ Zone III } & Mg3 & 9 & 6 & 267 & 51 & 0.71 & 1.39 & 2.20 & 1.80 & 0.32 & 0.77 \\
\hline & Hb3 & 16 & 9 & 308 & 117 & 1.38 & 1.12 & 2.77 & 2.20 & 0.50 & 0.51 \\
\hline & Pe3 & 11 & 11 & 34 & 338 & 1.97 & 0.98 & 2.40 & 2.40 & 0.82 & 0.41 \\
\hline
\end{tabular}




\section{Discussion}

\subsection{Fish Diversity}

The fish species reported in this study are characteristic of the ichthyogeographic province of Lower Guinea [28] [29], with the exception of Oreochromis niloticus and Heterotis niloticus, which were introduced into this part through fish farming [30] [31] [32] [33]. Overall, over $60 \%$ of species reported have marine affinity (Bostrychus africanus, Caranx fischeri, C. hippos, Dormitator lebretonis, Eleotris daganensis, Elops lacerta, Ethmalosa fimbriata, Eucinostomus melanopterus, Kribia nana, Mugil bananensis, Mugil curema, Mystriophis rostellatus, Neochelon falcipinnis, Parachelon grandisquamis, Pomadasys jubelini, Porogobius schlegelii, Sphyraena guachancho, Trachinotus teraia and T. ovatus). It is known that lagoons, with their ecotonal roles, host several marine species [4] [9]. According to [10], a significant proportion of the fish species composing neritic populations of African coasts is likely to enter estuaries and neighboring lagoons for various durations and at various stages. African continental waters are home to species of marine origin that have adapted to fresh waters or that migrate seasonally or sporadically between the sea and inland waters [34].

The species listed in this lagoon $(72.41 \%$ in the rainy season and $90 \%$ in the dry season) are species which constitute the fundamental lagoon population and the very base of lagoon populations by their permanence, their abundance and their essential role that they hold in the ecology and the halieutic economy of these ecosystems [4]. They are euryhaline species that adapt to any range of salinity.

\subsection{Season Effects on Fish Diversity and Distribution}

The seasonal variations show that in the rainy season the Malonda lagoon was more diversified (29 species against 20 in the dry season) and more abundant (1516 against 768 specimens). This difference in both abundance and specific richness could be explained by the fact that during the rainy season the Malonda lagoon opens (artificially by fishermen for 3 years) to the ocean several times. The opening of the lagoon on the one hand and the desalination of the water by continental inflows on the other hand allow both marine and continental species to enter it. This could also be due to the fact that during the rainy season there is an abundance of food and it is a favorable breeding season for many species. In this regard, [35] have argued that the period and duration of the ocean opening phase play an essential role in the diversity and abundance of fish in a lagoon system. Seasonal variations are very marked both in terms of stand composition and structure [36]. The hydrological variability resulting from the seasonal distribution of rainfall or the interannual variability of rainfall has important consequences on the biology and dynamics of fish populations [37].

Continental forms dominate in the rainy season while marine forms dominate in the dry season. In fact, in the dry season, the lagoon is completely closed and the exchanges at the mouth are made by infiltration. With the low inflows of 
continental water and also evaporation during this period, the water remains saltier, especially towards the mouth $(0.67 \pm 0.25 \mathrm{ppt}$ in the rainy season against $3.39 \pm 0.23 \mathrm{ppt}$ in the dry season). This explains the presence of marine species in the Pe3 station. According to [10], salinity and temperature are selective variables of the lagoon environment.

The study of the physical parameters of a station and of the species that colonize it makes it possible to determine the relationships between the environment and the species, and to identify the preferences of a species in terms of ecological factors [34]. According to the RDA (Figure 4 and Figure 5), four variables in the rainy season in particular, depth, mud, transparency and nitrogen and three variables in the dry season, namely mud, nitrogen and oxygen influence the distribution of species. [10] reported that the composition, distribution and abundance of communities in estuarine and lagoon waters are strongly influenced by salinity, temperature, turbidity, dissolved oxygen concentration. Seasonal variations are very marked, both in terms of stand composition and structure [34]. In the rainy season, the species are concentrated in the shallow stations, in particular the stations $\mathrm{Hb} 2, \mathrm{Hb} 3, \mathrm{Mg} 3$ and Mg2. These stations constitute rich habitats favorable to the development of planktonic species adapted to the nutritional needs of juveniles.

The grasses and stilt roots of Rhizophora sp. provide fish with shelter to escape predators, refuge, nursery and breeding grounds. Mangroves are irreplaceable habitats for many fish species [15]. Also, these stations have a high silt rate. The muddy substrate increases the fertility of the water, the abundance of food [33]. According to [34], an essential reason for a fish to frequent certain types of environment is the opportunity to find food suitable for its size and physiological requirements. The Pe 2 and $\mathrm{Pe} 3$ stations are negatively correlated with the silt; they have a sandy-rocky substrate and are colonized by the typically marine species (Caranx fischeri, C. hippos, Pomadasys jubelini and Trachinotus ovatus) for the Pe3 station and the continental species (Oreochromis niloticus and Odaxothrissa ansorgii) for the Pe2 station.

In the dry season, marine species are concentrated in the Pe 3 station, which is positively correlated with nitrogen. The Elops lacerta, Hepsetus lineata, Mugil curema, Oreochromis schwebischi, and Sarotherodon nigripinnis dolloi species more often frequent the muddy sites (Mg1, Hb1, Pe1 and Mg2). The Pe2, Hb2 and $\mathrm{Mg} 3$ stations, positively correlated with oxygen, harbor the species Coptodon guineensis, Hemichromis elongatus, Nannopetersius ansorgii et Porogobius schlegelii.

A species of fish maintains itself in a hydrosystem in the long term to the extent that it finds there a set of conditions that allow it, among other things, to grow and reproduce [38]. These very marked seasonal variations in the population are induced by changes in the environment, the abundance and distribution of freshwater inputs. Lagoons perform an extremely important and sometimes essential function for the completion of the biological cycle of certain fish [7] [10]. For both seasons, we observe an increasing gradient of the specific richness 
from upstream (the freshwater zone) to downstream (towards the mouth). In this regard, [39] specified that the physical conditions present in a watercourse, from upstream to downstream, induce a response from biological communities, with a gradual change depending on the capacities of the species. to adapt to environmental conditions and available food resources. This longitudinal zoning is accompanied by an increase in species richness by increasing the heterogeneity and volume of the habitat [20] [40]. The low diversity of stations in zone I (Pe1 and $\mathrm{Mg} 1$ stations) upstream may be due to the action of human activities carried out in the zone, in particular the sand quarry, fish ponds, excessive fishing by riparian fishermen. This area is near the village of Fouta and is subject to strong human pressure.

\subsection{Ecological Health of Malonda Lagoon}

The diversity indices provide information on the state of health of the lagoon in space and time. Three indices (,$H^{\prime}$ and $\mathrm{R}$ ) were calculated based on the abundances. These indices are of great importance in diagnosing the ecological health of an aquatic ecosystem [24]. The results show that most stations show indices that do not come close to their maximum values $\left(H_{\max }^{\prime}\right.$ for $H^{\prime}$ and 1 for $\mathrm{R}$ ) for both seasons. In the rainy season, four out of nine stations (Mg1, Pe1 and $\mathrm{Pe} 2$ and $\mathrm{Pe} 3$ ) have indices which approach the maximum values. These values show that these stations are not yet disturbed. The cash is distributed in an equitable manner within these stations. According to [41], $H^{\prime}$ is high when there is no imbalance in the number of individuals within each species. According to [42], the value of $\mathrm{R}$ varies between zero (0) when a single species dominates or one (1) when all species have the same abundance. The values which are close to 0 in particular for the Mg2 and Mg3 stations could be explained by the presence of a very abundant species Nannopetersius ansorgii which alone represents $94 \%$ for the $\mathrm{Mg} 2$ station and $84 \%$ for the $\mathrm{Mg} 3$ station of the total abundance. The dominance of a species at a site could mean an increase in the influence of human activities [43].

In the dry season, only one Pel station presented the values of $H^{\prime}$ and $\mathrm{R}$ close to the maximum values. The other stations have values of $\mathrm{R}$ far from 1 , especially the station Pe3. This could be the result of the presence of the species Odaxothrissa ansorgii which alone accounts for $72 \%$ of the total abundance. These results show that this lagoon is already suffering from human imprints. [44] pointed out that the equatorial ecoregion of the southwest coast in which Malonda is located has been identified as being highly vulnerable to human impacts. In addition, it is subject to increased overexploitation of fish stocks. Although far from the city, it is much frequented by fishermen who engage in artisanal fishing with non-selective gear. Malonda lagoon is located in an oil zone. Oil exploitation is one of the main activities identified as polluting the aquatic systems of the southwest coast of the equatorial ecoregion [12].

The high values of the indices $\left(H^{\prime}\right.$ and $\left.\mathrm{R}\right)$ would show an even distribution 
and a good diversification of species within a station [17]. When the calculated $\mathrm{H}^{\prime}$ and $\mathrm{R}$ indices approach their maximum values, this proves that all species in the community constitute an excellent distribution of abundance and that the environment is in good ecological health [12] [24]. In our case for most stations, the values show a poor distribution of fish abundance, consequently a poor ecological state of the lagoon.

\section{Conclusion}

The present study focused on the analysis of the diversity and spatio-temporal distribution of the ichthyofauna of the Malonda lagoon. The analysis provided a good knowledge of the diversity of fish in these still poorly known environments, and an understanding of the relationship that exists between the species and the environment in which they live. The results showed that the distribution of fish is a function of environmental parameters. In the rainy season, four environmental variables influence the distribution in four habitats and in the dry season, a single variable influences the distribution in four habitats. Analysis of the diversity indices showed that the Malonda Lagoon is not in good ecological condition. Monitoring of environmental parameters and the establishment of biological indicators could make it possible to better monitor the lagoon and ensure its balance. Other analyzes, in particular on the biology of the harvested species (food habit, reproduction) should be considered to understand the preference of certain habitats by the species.

\section{Acknowledgements}

We would like to thank Martin Bassafoula and Daniel Bavedila, the technician of the environment and oceanography laboratory, for help in the field. The fieldwork of THDL was provided by IRSEN institution (Republic of the Congo).

\section{Conflicts of Interest}

The authors declare no conflicts of interest regarding the publication of this paper.

\section{References}

[1] Chabanne, D. (2007) Les Catégories bioécologiques des espèces de poissons des estuaires et lagunes de l'Afrique de l'Ouest. Université des sciences et techniques du Languedoc Centre International d'Études Supérieures en Sciences Agronomiques, $33 \mathrm{p}$.

[2] Teugels, G.G., Ozouf-Costaz, C., Legendre, M. and Parrent, M. (1992) A Karyological Analysis of the Artificial Hybridization between Clarias gariepinus Burchell, 1822 and Heterobranchus longi Filis Valenciennes, 1840 Pisces, Clariidae. Journal of Fish Biology, 40, 81-86. https://doi.org/10.1111/j.1095-8649.1992.tb02555.x

[3] Mamoneke, V. and Teugels, G.G. (1993) Faune des poissons d'eaux douces de la réserve de la Biosphère de Dimonika (Mayombe, Congo). Annale Musée Royal Afrique Centrale, MRAC (Tervuren) and U.N.E.S.C.O, Vol. 272, 126 p.

[4] Albaret, J.-J. (1994) Les poissons: Biologie et peuplements. In:Durand, J.-R., Dufour, 
P., Guiral, D. and Zabi, S.G., Eds., Environnement et ressources aquatiques de Côte-d Ivoire, Tome 2: Les milieux saumâtres, L'exemple de la lagune Ébrié, Office de la Recherche Scientifique et Technique Outre-Mer (ORSTOM), Paris, 239-279.

[5] Villanueva, M.C.S. (2004) Biodiversité et relations trophiques dans quelques milieux estuariens et lagunaires de l'Afrique de l'ouest: Adaptations aux pressions environnementales. Thèse de doctorat $(\mathrm{PhD})$, Toulouse, $278 \mathrm{p}$.

[6] Mostarih, M.M.M., Faid El Madani, F.E., Yahya, H.S.A., Hachemi, O.E., Abdellaoui, S. and Chafi, A. (2016) Evaluation physico-chimique de la qualité de l'eau de la lagune de Nador-Nord du Maroc oriental après l'ouverture de la nouvelle passe. Journal of Materials and Environmental Science, 7, 4795-5809. http://www.jmaterenvironsci.com

[7] Wootton, R.J. (1992) Fish Ecology. Blackie and Son, Glasgow, 212 p. https://doi.org/10.1007/978-94-011-3832-1

[8] Albaret, J.-J. (1987) Les peuplements de poissons de la Casamance Sénégal en période de sécheresse. Revue d Hydrobiologie tropicale, 20, 291-310.

[9] Diouf, P.S. (1996) Les peuplements de poissons des milieux estuariens de l'Afrique de l'Ouest: l'exemple de l'estuaire hyperhalin du Siné-Saloum. Office de la Recherche Scientifique et Technique Outre-Mer (ORSTOM), Paris, Thèse et documents microfichés, Vol. 156, 303 p.

[10] Albaret, J.-J. (2006) Les peuplements des estuaires et des lagunes. In: Lévêque, C. and Paugy, D., Eds., Les poissons des eaux continentales africaines: Diversité, écologie, utilisation par l homme, Institut de Recherches pour le Développement (IRD), Paris, 355-379.

[11] Albaret, J.-J. and Diouf, P.S. (1994) Diversité des poissons des lagunes et des estuaires ouest-africains. In: Teugels, G.G., Guégan, J.-F. and Albaret, J.-J., Eds., Diversité biologique des poissons des eaux douces et saumâtres d'Afrique, Synthèses géographiques, Annales, Musée Royal Afrique Centrale, Zoologie, Tervuren, Vol. 275, 165-177.

[12] Ibala Zamba, A., Boungou, M., Louvinguila, T.H.D., Mamonekene, V., Kombo, R., Kamba, E., Boukou, G., Mikembi, L.B., Ngot, F.H.P. and Akouango, P. (2020) Anthropogenic Impacts on Fish Populations in Lake Cayo (Republic of Congo, Central Africa). Open Journal of Ecology, 10, 757-767. https://doi.org/10.4236/oje.2020.1012046

[13] Barré, N. (2011) Lagunes et marais littoraux: Fonctionnement, valeurs, enjeux et menaces. Pôle relais lagunes méditerranéennes, $59 \mathrm{p}$.

[14] Kouassi, A. M. (2005) Hydrochimie et qualité des eaux de deux lagunes tropicales de Côte d'Ivoire (Ebrié, Grand Lahou). Thèse de doctorat $(\mathrm{PhD})$, Université de Cocody, Abidjan, $147 \mathrm{p}$.

[15] Issola, Y., Kouassi, A.M., Dongui, B.K. and Biemi, J. (2008) Caractéristiques physico-chimiques d'une lagune côtière tropicale: Lagune de Fresco (Côte d'Ivoire). Afrique Science, 4, 368-393. https://doi.org/10.4314/afsci.v4i3.61696

[16] Baran, E. (2015) Dynamique spatio-temporel le des peuplements de poissons estuariens en Guinée Relations avec le milieu abiotique. Thèses et documents microfichés No.142 Office de la Recherche Scientifique et Technique Outre-Mer (ORSTOM), Paris, $245 \mathrm{p}$.

[17] Ibala Zamba, A., Vreven, E., Mamonekene, V. and Snoeks, J., (2019) Fish Community Assemblages in Relation to Environmental Variables in the Lefini River, Middle Congo River Basin (Republic of Congo). Cybium, 43, 83-95.

[18] Fricke, R., Eschmer, W.N. and Fong, J.D. (2020) Eschmeyer's Catalog of Fishes. 
http://researcharchive.calacademy.org/research/ichthyology/catalog/SpeciesByFamil y.asp

[19] Kamdem Toham, A. and Teugels, G.G. (1999) First Data on an Index of Biotic Integrity (IBI) Based on First Assemblages for the Assessment of the Impact of the Deforestation in a Tropical West African River System. Hydrobiologia, 397, 29-38. https://doi.org/10.1023/A:1003605801875

[20] Batiabo Mikembi, A.L, Ibala Zamb, A., Mamonekene, V., Poaty Ngot,.H.F., Dembe Louvinguila, T.H. and Vouidibio J. (2019) Diversity and Distribution of Fish Species along the Loua River, Lower Congo River Basin (Republic of the Congo, Central Africa). International Journal of Fisheries and Aquatic Studies, 7, 171-176.

[21] Liyandja, T.L.D., Ibala Zamba, A., Sefu, C.A., Dianzuangani, D.L., Konda, R.K., Monsembula Iyaba, R.J.C. and Mbimbi, J.J.M.N. (2019) Environmental Influences on Fish Species Distribution in the Musolo River System, Congo River Basin (Democratic Republic of the Congo, Central Africa). European Scientific Journal, 15, 192-209. https://doi.org/10.19044/esj.2019.v15n33p192

[22] Ter Braak, C.J.F. and Šmilauer, P. (2003) Canoco 4. Cambridge University Press, Cambridge, $242 \mathrm{p}$.

[23] Lande, R. (1996) Statistcs and Partitioning of Species Diversity, and Similarity among Multiple Communities. Oikos, 76, 5-13. https://doi.org/10.2307/3545743

[24] Lobry, J., Gascuel, D. and Domain, F. (2003) La biodiversité spécifique des ressources démersales du plateau continental guinéen: Utilisation d'indice classique pour un diagnostic sur l'évolution des écosystèmes. Aquatic Living Resources, 16, 59-68. https://doi.org/10.1016/S0990-7440(03)00010-X

[25] Clarke, K.R. and Gorley, R.N. (2001) Primer v5: User Manual/Tutorial. Primer-E Ltd., Plymouth, 91 p.

[26] Shannon, C.E. (1948) A Mathematical Theory for Communication. Bell System Technical Journal, 27, 623-656. https://doi.org/10.1002/j.1538-7305.1948.tb00917.x

[27] Pielou, E.C. (1966) The Measurement of Diversity in Different Types of Biological Collections. Journal of Theoretical Biology, 13, 131-144.

https://doi.org/10.1016/0022-5193(66)90013-0

[28] Stiassny, M.L.J., Teugels, G.G. and Hopkins, C.D. (2007) Poissons d'eaux douces et saumâtres de basse Guinée, ouest de l'Afrique centrale. Vol. 1, IRD (Paris), MNHN (Paris), MRAC (Tervuren), collection faune et flores tropicales, Vol. 42, $800 \mathrm{p}$.

[29] Stiassny, M.L.J., Teugels, G.G. and Hopkins, C.D. (2007) Poissons d'eaux douces et Saumâtres de basse Guinée, Ouest de l'Afrique Centrale. Vol. 2, Institut De Recherche Pour Le Développement, Muséum National d'Histoire Naturelle, Musée Royal de l'Afrique Central, Paris, Tervuren, Vol. 42, 603 p.

[30] Welcomme, R.L. (1988) International Introductions of Inland Aquatic Species. Fisheries Technical Paper, Vol. 294, FAO, Rome, 318 p.

[31] Moreau, J., Arrignon, J. and Jubb, R.A. (1988) Les introductions d'espèces étrangères dans les eaux continentales africaines. Intérêt et limites. In: Lévêque, C., Bruton, M.N. and Ssentongo, G.W., Eds., Biologie et écologie des poissons deau douce africains, Office de la Recherche Scientifique et Technique Outre-Mer (ORSTOM), Travaux et documents, Paris, Vol. 216, 395-425.

[32] Lévêque, C. (1997) Introductions de nouvelles espèces de poissons dans les eaux douces tropicales: Objectifs et conséquences. Bulletin Français de la Pêche et de la Pisciculture, 344-345, 79-91. https://doi.org/10.1051/kmae:1997012

[33] Lacroix, E. (2004) Pisciculture en milieu tropical. GFA terra systems. 225 p.

[34] Lévêque, C. and Paugy, D., (2006) Les poissons des eaux continentales africaines 
Diversité, écologie, utilisation par l'homme. Institut de Recherches pour le Développement (IRD), Paris, 573 p.

[35] Whitfield, A.K. and Kok, H.M. (1992) Recruitment of Juvenile Marine Fishes into Permanently Open and Seasonally Open Estuarine Systems on the Southern Coast of South Africa. Ichthyology Bulletin, 57, 1-39.

http://hdl.handle.net/10962/d1019801

[36] Albaret, J.-J. and Ecoutin, J.M. (1990) Influence des saisons et des variations climatiques sur les peuplements de poissons d'une lagune tropicale en Afrique de l'Ouest. Acta Oecologica, 11, 577-583.

[37] Lévêque, C. (2017) Variability of Climate and Hydrobiological Systems. In: Paugy, D., Leveque, C. and Otero, O., Eds., The Inland Water Fishes of Africa: Diversity, Ecology and Human Use, Institut de recherche pour le développement (IRD), Royal Museum for Central Africa (RMCA), 33-50.

[38] Lemoalle, J. (2006) La diversité des milieux aquatiques. In: Levêque, C. and Paugy, D., Eds., Les poissons des eaux continentales africains: Diversité, écologie, utilisation par Phomme, Institut de Recherches pour le Développement (IRD), Paris, 11-30.

[39] Lévêque, C. and Paugy, D. (2017) Fish Communities in River Systems and Associated Stations. In: Paugy, D., Leveque, C. and Otero, O., Eds., The Inland Water Fishes of Africa: Diversity, Ecology and Human Use, Institut De Recherche Pour Le Développement, Musée Royal de l'Afrique Central, Paris, Tervuren, 349-360. https://doi.org/10.4000/books.irdeditions.25241

[40] Hugueny, B. (1990) Richesse des peuplements de poissons dans le Niandan (haut Niger, Afrique) en fonction de la taille de la rivière. Revue d Hydrobiologie Tropicale, 23, 351-364.

[41] Ibala Zamba, A. (2010) Faune des poissons des rivières Luki et Léfini (Bassin du Congo): Diversité et écologie. Thèse de doctorat $(\mathrm{PhD}), \mathrm{KU}$ Leuven, Leuven, Belgique, $452 \mathrm{p}$.

[42] Barbault, R. (1992) Écologie des populations et des peuplements. Des théories aux faits. Masson, Paris, 200 p.

[43] Barbour, M.T., Stribling, J.B. and Karr, J.R. (1999) Multimetric Approach for Establishing Biocriteria and Measuring Biological Condition. In: Davis, W. and Simon, T.P., Eds., Biological and Criteria: Tools for Water Resource Planning and Decision Making, CRC Press, Boca Raton, 63-77.

[44] Thieme, M.L., Abell, R., Stiassny, M.L.J. and Skelton, P. (2005) Freshwater Ecoregions of Africa and Madagascar. A Conservation Assessment. Wold Wildlife Fund, Gland, $431 \mathrm{p}$. 